\title{
Renal tumouroids: challenges of manufacturing 3D cultures from patient derived primary cells
}

\author{
Agata Nyga ${ }^{1,2}$ (D) Katerina Stamati $^{1} \cdot$ Patricia A. Redondo ${ }^{1} \cdot$ Tayebeh Azimi $^{1} \cdot$ Andrew Feber $^{1,3} \cdot$ Joana B. Neves $^{1,4}$. \\ Rifat Hamoudi ${ }^{1,5} \cdot$ Nadège Presneau $^{6} \cdot$ Soha El Sheikh ${ }^{7} \cdot$ Maxine G. B. Tran ${ }^{1,4} \cdot$ Mark Emberton $^{8,9}$. \\ Marilena Loizidou ${ }^{1} \cdot$ Umber Cheema $^{8}$
}

Received: 17 December 2021 / Accepted: 4 January 2022 / Published online: 31 January 2022

(c) Crown 2022

\begin{abstract}
Recent advancements in 3D in vitro culture have allowed for the development of cancer tissue models which accurately recapitulate the tumour microenvironment. Consequently, there has been increased innovation in therapeutic drug screening. While organoid cultures show great potential, they are limited by the time scale of their growth in vitro and the dependence upon commercial matrices, such as Matrigel, which do not allow for manipulations of their composition or mechanical properties. Here, we show a straightforward approach for the isolation and culture of primary human renal carcinoma cells and matched non-affected kidney. This approach does not require any specific selection for cancer cells, and allows for their direct culture in amenable 3D collagen-based matrices, with the preservation of cancer cells as confirmed by NGS sequencing. This method allows for culture of patient-derived cancer cells in 3D microenvironment, which can be used for downstream experimentation such as investigation of cell-matrix interaction or drug screening.
\end{abstract}

Keywords 3D cancer cultures $\cdot$ Patient derived 3D cultures $\cdot$ Renal cancer $\cdot$ Renal cancer mutations $\cdot$ Tumouroids

$\begin{array}{ll}\text { Abbreviations } \\ \text { 2D } & \text { Two dimensional } \\ \text { 3D } & \text { Three dimensional } \\ \text { CA9 } & \text { Carbonic anhydrase IX } \\ \text { ccRCC } & \text { clear cell renal cell carcinoma } \\ \text { CK8 } & \text { Cytokeratin 8 } \\ \text { FACS } & \text { Fluorescence-activated cell sorting } \\ \text { FBS } & \text { Foetal bovine serum }\end{array}$

Agata Nyga

anyga@mrc-lmb.cam.ac.uk

$\triangle$ Umber Cheema

u.cheema@ucl.ac.uk

1 Research Department of Surgical Biotechnology, Division of Surgery \& Interventional Science, University College London, London, UK

2 Cell Biology Division, MRC Laboratory for Molecular Biology, Cambridge Biomedical Campus, Francis Crick Avenue, Cambridge CB2 0QH, UK

3 Centre for Molecular Pathology, Royal Marsden NHS Trust, London, UK

4 Specialist Centre for Kidney Cancer, Royal Free London NHS Foundation Trust, London, UK

\section{OCA Organoid culture assay}

RCC Renal cell carcinoma

\section{Introduction}

In vitro cell-line cultures have been invaluable tools to study the mechanisms and interrogate the molecular events leading to oncogenesis, tumour growth and aggressiveness.

5 Sharjah Institute for Medical Research, College of Medicine, University of Sharjah, Sharjah, United Arab Emirates

6 School of Life Sciences, University of Westminster, London, UK

7 Cellular Pathology Department, Royal Free London Foundation Trust, London, UK

8 Centre for 3D Models of Health and Disease, Research Department of Targeted Intervention, Division of Surgery \& Interventional Science, University College London, Charles Bell House,43-45 Foley Street, London W1W 7TS, UK

9 Department of Urology, University College London Hospitals NHS Foundation Trust, London, UK 
However, cancer cell heterogeneity means that capturing the range of cell specific responses is difficult using cell lines. For renal cancer, over $60 \%$ of somatic mutations are not detectable in all tumour regions, i.e. are not clonal, indicating significant tumour heterogeneity (Gerlinger et al. 2012), and highlighting the need for in vitro models that can recapitulate both patient and tumour heterogeneity.

Three dimensional (3D) in vitro cultures of human tumours go back to the late 70 s with cultures in gelatin foam sponges and hollow fiber matrices producing glandular structures "organoids" (Rutzky et al. 1979). This was followed by cancer cell expansion through xenografting in mice (Köpf-Maier and Zimmermann 1991) to develop an organoid culture assay (OCA) to test drug sensitivity, the first 3D model to test individual tumours' drug sensitivity and resistance in vitro - "anti-oncogram" (Köpf-Maier and Kolon 1992). It took another 15 years to develop improved methods to culture normal human epithelial organoids (Karthaus et al. 2014; Sato et al. 2011, 2009), and human tumour organoids, or tumouroids, without the need to first passage the cells in mice (Boehnke et al. 2016; Fujii et al. 2016; Gao et al. 2014; van de Wetering et al. 2015).

Renal cell carcinoma (RCC) incidence rates have been rising since the 1970s, partly due to increased use of imaging. Despite the advances in new immunotherapies for advanced disease, there has been no impact on overall survival, highlighting the need for personalised targeted therapy rather than a 'one-size fits all' approach. RCC is not a uniform malignant phenotype, and has many subtypes, including clear cell (ccRCC), papillary and chromophobe; each differing in relative aggressiveness, pattern of reoccurrence and in overall prognosis (Kuroda and Tanaka 2014). Renal cell carcinoma in vitro cultures using primary human cells or human tumour organoids are sparse. Early studies reported success rates of $12.7 \%$ in establishing continuous renal cancer cell lines (Ebert et al. 1990), while more recent studies show that primary RCC cells can be grown in vitro in a standard cell culture medium (Dulbecco's modified Eagle's medium with nutrient mixture F-12, or RPMI 1640) with supplementation of serum and human transferrin. Still, normal kidney cells showed greater proliferation than the primary tumour cells in $2 \mathrm{D}$ (Valente et al. 2011), and formation of 3D organoids-100\% for normal kidney cells and $67 \%$ for ccRCC (Grassi et al. 2019). ccRCC 2D cultures (from Grade 2 and 3 tumours) were also established in serum-supplemented DMEM, with over $90 \%$ of cells expressing cytokeratin, vimentin and CD13, and over $60 \%$ of cells positive for carbonic anhydrase IX (CA9), a marker specific for ccRCC. These cultures also showed a strong correlation in genomic profiles with the tumour tissue from which they were derived (Cifola et al. 2011). On the other hand, metastatic RCC were cultured in 2D in CellGro SCGM medium, a specialized medium for expansion of haematopoietic and progenitor cells, with over $90 \%$ of cultured cells expressing CD10 (marker of certain RCC subtypes) (Dragoni et al. 2014). However, the limitations of the 2D cultures of primary human RCC cells is still reported to be their decline in proliferation and growth arrest after few passages. Addition of ROCK1 inhibitor (to prevent anoikis) during tumour dissociation steps significantly increased the clonogenic frequency and tumourigenic potential of the primary ex vivo ccRCC samples (Gedye et al. 2016), and was used to generate an organoid biobank of paediatric kidney tumours (Calandrini et al. 2020).

To address the challenges in studying primary human RCC in vitro, we describe a method of manufacturing 3D renal cancer masses (renal tumouroids) from cells isolated from patients with RCC. We took a novel approach, where we recapitulated the 3D matrix architecture and kidney tissue stiffness (Bensamoun et al. 2011). Isolated primary cells were both cultured in 2D conditions or in the 3D matrix composed of collagen type I supplemented with other matrix proteins. We used a patented and semi-automated process, based on our previously reported UCL patent (Brown et al. 2005) to compress the cell populated hydrogel and create dense tumouroids (Magdeldin et al. 2017; Nyga et al. 2013). We describe several challenges in terms of characterization of cells, evaluation of growth conditions, towards establishing a robust pathway from clinic to bench.

\section{Materials and methods}

\section{Surgical tissue access and collection}

Tissue samples $(\mathrm{n}=24)$ were obtained with informed consent from patients undergoing nephrectomy at the Specialist Centre for Kidney Cancer, Royal Free Hospital NHS Foundation Trust (London, UK; REC reference number: 16/ WS/0039). The following criteria were used for exclusion: cystic tumours, risk of compromising pathologic staging as judged by the pathology team, the patient having received chemotherapy, biologic targeted agents or radiotherapy less than 6 months before surgical intervention, and inability to provide informed consent. Information collected for each sample included: collection date, age, gender, date of diagnosis, association with hereditary syndromes, family history of 1st degree relative with renal cancer, clinical TNM staging, previous biopsy, and the presence of metastasis at diagnosis.

\section{Tissue handling}

\section{Tissue transfer}

Samples were transported to the laboratory on ice in Wash Medium: RPMI (Cat\# 21875091 ThermoFisher, Loughborough, UK) supplemented with: 100 units penicillin and $100 \mu \mathrm{g} / \mathrm{ml}$ streptomycin (Cat\# P0781 Sigma-Aldrich, 
Gillingham, UK), $100 \mu \mathrm{g} / \mathrm{ml}$ gentamicin (Cat\# G1272 Sigma-Aldrich), and $10 \mu \mathrm{g} / \mathrm{ml}$ Fungizone (Cat\# A9528 Sigma-Aldrich) for immediate processing, or stored in Wash Medium at $4{ }^{\circ} \mathrm{C}$ until processed (24-48 $\mathrm{h}$ following surgery).

\section{Primary cell isolation}

Following removal of macroscopic fat and/or necrotic tissue, the sample was weighed and measured, and its gross morphology recorded. Tissues were finely minced with scalpel blades and digested with $1 \mathrm{X}$ collagenase/hyaluronidase (STEMCell Technologies, Cambridge, UK) in DMEM or with Tumour Dissociation Kit enzymes $(4.7 \mathrm{ml}$ of Wash Medium, $200 \mu$ l enzyme H, $100 \mu$ l enzyme R, $25 \mu$ l enzyme A, per 1g of tissue, Miltenyi Biotec, Surrey, UK) in a Petri dish. The dish was incubated for $60 \mathrm{~min}$ at $37^{\circ} \mathrm{C}$ on a shaker, and samples were inspected and further minced as necessary.

The mixture was resuspended in $20 \mathrm{ml}$ of Wash Medium (per $1 \mathrm{~g}$ of tissue), and filtered using 100, 70 and $40 \mu \mathrm{m}$ cell strainers (Fisherbrand, Loughborough, UK). The filtrate was centrifuged at $300 \mathrm{~g}$ for 7 minutes. The cell pellet was resuspended in $24 \mathrm{ml}$ of Wash Medium, and layered on top of $9 \mathrm{ml}$ of Histopaque (Cat\# 10771, Sigma-Aldrich) and centrifuged at $650 \mathrm{~g}$, for 20 minutes. The buffy coat with cells was removed and washed with $20 \mathrm{ml}$ of Wash Medium by centrifugation at $300 \mathrm{~g}$ for $7 \mathrm{~min}$. Cells were resuspended in Wash Medium and counted using Luna-II Automated Cell Counter (Cat\# L40002, LabTech, Heathfield, UK).

\section{Separation of cell types}

The mixed cell population obtained above underwent further separation of specific cell types. Separation was carried out for a subset of samples $(n=6)$ which yielded a high number of cells, to investigate both the presence of different cell types and to enrich the cancer cell population.

Fibroblast isolation To positively select for fibroblasts, $10^{6}$ cells from the total isolate were resuspended in $80 \mu \mathrm{l}$ of Sorting Buffer ( $0.5 \%$ bovine serum albumin (BSA) and 2 mM EDTA (Sigma-Aldrich) in PBS (ThermoFisher). $20 \mu \mathrm{l}$ of anti-fibroblast beads (Cat\# 130-050-601, Miltneyi Biotec) were added, mixed and incubated for $30 \mathrm{~min}$ at room temperature (RT). $500 \mu \mathrm{l}$ of Sorting Buffer was added to the sample and mixed gently. Beads with positively selected cells were isolated using a LS column in a magnetic field (MidiMACS Separator, MACS MultiStand, Cat\# 130-042301, Miltenyi Biotec), collecting both non-labelled and labelled cells. Fibroblasts were plated in NUNC flasks (5 x $10^{5}$ cells per $75 \mathrm{~cm}^{2}$, Sigma-Aldrich) in Fibroblast Medium (Fibroblast Growth Medium 2, Cat\# 23020, PromoCell, Heidelberg, Germany) with 100 units penicillin and $100 \mu \mathrm{g} /$ $\mathrm{ml}$ streptomycin.
Endothelial cell isolation To positively select for the endothelial population, the mixed cell population was resuspended in $60 \mu \mathrm{l}$ of Endothelial Medium (EGM-2 MV medium, Cat\# CC-3202, Lonza, Basel, Switzerland) containing penicillin/streptomycin, per $10^{6}$ cells and $20 \mu \mathrm{FcR}$ blocking reagent. $20 \mu \mathrm{l}$ of anti-CD31 beads (Cat\# 130-091935, Miltneyi Biotec) were added, mixed and incubated for 15 min at $4{ }^{\circ} \mathrm{C}$. The cell mixture was resuspended in $1 \mathrm{ml}$ of Endothelial Medium and centrifuged at $300 \mathrm{~g}$ for $3 \mathrm{~min}$. Beads with positively selected cells and non-labelled cells were isolated using a LS column in a magnetic field. CD $31^{+}$ cells were plated at $5 \times 10^{5}$ cells per $75 \mathrm{~cm}^{2}$ on collagencoated $(0.1 \mathrm{mg} / \mathrm{ml}$ rat tail collagen type I in PBS, Cat\# 60-30-810, First Link UK, Wolverhampton, UK) cell culture flasks in supplemented Endothelial Medium.

\section{Culture in 2D and 3D}

\section{D cultures}

Cells not processed for specific subtype isolation ("Total cell isolate") and non-labelled cells obtained following the beadisolation steps ("Post-sorting cell isolate") described above, were plated (NUNC plates, $5 \times 10^{5}$ cells $/ 75 \mathrm{~cm}^{2}$ ) in Cancer Medium (RPMI, ThermoFisher, supplemented with $10 \%$ Foetal Bovine Serum (FBS, ThermoFisher), and penicillin/ streptomycin. Cells were incubated at $37^{\circ} \mathrm{C}$ in a humidified atmosphere and $5 \% \mathrm{CO}_{2}$. Medium was changed every 2 to 5 days. Cells were monitored under light microscopy every 2 to 3 days. If no cell growth was observed within 15 days or no further cell colonies formed at day 30 , samples were disposed of. Cells were passaged at 70-80\% confluency.

\section{Spheroid culture}

Total or Post-sorting cell isolate were tested for their spheroid forming ability. For this, cells were placed in low attachment cell culture plates $\left(10^{4}\right.$ cells/well, 6 -well plate) and cultured in Spheroid Medium (Advanced DMEM/F12 (Cat\# 12634-028, ThermoFisher) supplemented with $2 \mathrm{mM}$ L-glutamine, $1 \times$ N2 supplement (Cat\# 17502-048, ThermoFisher), 1x B27 supplement (Cat\# 17504-001, ThermoFisher), $1 \mathrm{mM} \mathrm{N}$-acetyl-L-cysteine (NAC, Cat \#A9165, Sigma-Aldrich), penicillin/streptomycin) or in STEM Cell Medium (Cat\# 130-104-368, Miltenyi Biotec). Formation of spheroids was observed under light microscopy and images were taken to record spheroid size. If no spheroids were formed within 7 days, samples were disposed of.

\section{Tumouroid culture}

The $3 \mathrm{D}$ cultures were manufactured using the RAFT ${ }^{\mathrm{TM}}$ system (Real Architecture for 3D Tissue, Cat\# 016-0R92, 
Lonza) as we previously described (Magdeldin et al. 2014). Briefly, cells (50-100, 000 cells per gel, or spheroids) were suspended on ice in a neutralised collagen type I solution (80\% rat tail collagen type I, $2.05 \mathrm{mg} / \mathrm{ml}, 10 \% 10 \mathrm{X}$ Minimal Essential Medium, Cat\# 21430020, ThermoFisher) with 50 $\mu \mathrm{g} / \mathrm{ml}$ laminin (Cat\# 734-1098, VWR, Lutterworth, UK) and cells in Cancer Medium (4.2\%).

The cell-collagen-laminin mixture was immediately plated ( $240 \mu \mathrm{l} /$ well in 96-well plates) and incubated for 15 min at $37{ }^{\circ} \mathrm{C}$ to allow for collagen polymerization. After polymerization, to increase collagen density, gels were compressed by placing absorbers on the top surface of each, to remove liquid (RAFT 3D system, Lonza) for $15 \mathrm{~min}$ at RT. Following this, absorbers were removed, and Cancer Medium or Spheroid Medium was added (200 $\mu$ l per well). Tumouroids were incubated at $37^{\circ} \mathrm{C}$ in a humidified atmosphere and $5 \% \mathrm{CO}_{2} .50 \%$ the medium was refreshed every 2 days.

\section{Immunofluorescence}

Tumouroids were fixed in $150 \mu$ l of $10 \%$ neutral buffered formalin (NBF) for $30 \mathrm{~min}$ at RT. Non-specific binding was blocked with $200 \mu$ of Blocking Buffer (1\% BSA, $0.3 \%$ Triton X-100 in PBS) for $1 \mathrm{~h}$ at RT. Tumouroids were incubated overnight in $100 \mu$ of primary antibody (Table 1) diluted in Blocking Buffer at $4{ }^{\circ} \mathrm{C}$. Secondary antibody diluted in Blocking Buffer was incubated for $2 \mathrm{~h}$ at RT (covered from light). Samples were mounted in medium with DAPI (Vectashield) and imaged using inverted fluorescent microscope (EVOS FL Cell Imaging System, ThermoFisher).

\section{Fluorescence-activated cell sorting (FACS)}

Cancer cell monolayers were gently detached from 2D tissue culture dishes using Tryple Select enzyme (4 $\mathrm{ml}$ per $75 \mathrm{~cm}^{2}$, Cat\# 12563-011, ThermoFisher). Firstly, cell suspension ( $5 \times 10^{5}$ cells) was stained for live and dead cells using Live/Dead ${ }^{\mathrm{TM}}$ Fixable stain kit (Near-IR, Cat\# L10119, ThermoFisher), followed by blocking the Fc receptor (Cat\# 564220, BD Biosciences, Wokingham, UK) in stain buffer ( $1 \%$ BSA, $0.09 \%$ sodium azide in PBS) for $10 \mathrm{~min}$ at RT. Cells were stained in $100 \mu$ of stain buffer and fluo-labelled antibody or isotype control (Table 2, antibodies concentrations were optimized using renal carcinoma cell lines CAKI-2 and ACHN, human endothelial cell line HUVEC, human dermal fibroblasts HDF and monocytic cell line U937) for $1 \mathrm{~h}$ at RT. Following staining, cells were fixed in $250 \mu \mathrm{l}$ Cytofix fixation buffer (Cat\# 554655, BD Biosciences, Berkshire, UK) for 15 min at $4{ }^{\circ} \mathrm{C}$. For intracellular staining, fixed cells were permeabilized in $1 \mathrm{ml}$ of ice-cold Phosflow Perm buffer III (Cat\# 558050, BD Biosciences) for $30 \mathrm{~min}$ on ice. Permeabilised cells were incubated for $1 \mathrm{~h}$ at RT in $100 \mu \mathrm{l}$ stain buffer with intracellular marker (vimentin,
Table 1 Primary antibodies (Abcam) used for fluorescent imaging
Table 2 Primary antibodies used for single cell analysis

\begin{tabular}{llllll}
\hline Antibody & Type & Species & Localisation & Dilution & Cat \# \\
\hline CK8 & Primary & Mouse & Membrane, Cell junction & $1: 200$ & ab9023 \\
CD31 & Primary & Rabbit & Cytoplasm & $1: 200$ & ab9498 \\
Vimentin & Conjugated & Mouse & Membrane \& cytoplasm & $1: 1000$ & ab195877 \\
Anti-Mouse & Secondary & Goat/Donkey & & $1: 500$ & ab150113/ab150108 \\
Anti-Rabbit & Secondary & Donkey & & $1: 500$ & ab150077 \\
\hline
\end{tabular}

\begin{tabular}{lllllll}
\hline Antibody & Fluorochrome & Dilution & Positive control & Negative control & Cat \# & Company \\
\hline CK-7/-8 & Alexa Fluor 647 & $1: 100$ & ACHN/CAKI-2 & HDF/HUVEC & 563,614 & BD Biosciences \\
CD44 & APC & $1: 100$ & U937/ACHN & HDF & 560,890 & BD Biosciences \\
CD45 & BV510 & $1: 100$ & U937 & HUVEC/HDF & 563,204 & BD Biosciences \\
CD31 & Alexa Fluor 647 & $1: 100$ & HUVEC & HDF & 561,654 & BD Biosciences \\
CD105 & BV421 & $1: 100$ & U937 & HDF & 563,920 & BD Biosciences \\
Vimentin & Alexa Fluor 488 & $1: 100$ & HDF & U937 & 562,338 & BD Biosciences \\
CA9 & PE & $1: 100$ & ACHN/CAKI-2 & HDF/HUVEC & FAB2188P & R\&D Systems \\
iso & PE & $1: 100$ & & & 554,680 & BD Biosciences \\
ISO & BV510 & $1: 100$ & & & 562,946 & BD Biosciences \\
iso & Alexa Fluor 647 & $1: 100$ & & & 557,714 & BD Biosciences \\
iso & Alexa Fluor 488 & $1: 100$ & & & 557,721 & BD Biosciences \\
iso & APC & $1: 100$ & & 555,745 & BD Biosciences \\
iso & BV421 & $1: 100$ & & 562,438 & BD Biosciences
\end{tabular}


CK-7/-8) antibody or isotype control. Cells resuspended in $1 \mathrm{ml}$ of staining buffer were assessed on a cell analyzer (BD LSRFortessa $^{\mathrm{TM}}$, BD Biosciences) using BD FACSDiva software (version 6.2).

\section{DNA extraction from fixed tumouroids}

DNA was extracted from tumouroids fixed in $10 \% \mathrm{NBF}$ using QIAamp DNA FFPE kit (\#56404, Qiagen, Manchester, UK) according to manufacturer's instructions. Briefly, 3-4 tumouroids from same patient were pooled together in $1.5 \mathrm{ml}$ microtube and resuspended in $180 \mu \mathrm{l}$ Buffer ATL, followed by incubation for $30 \mathrm{~min}$, addition of $20 \mu \mathrm{l}$ of proteinase $\mathrm{K}$ and quick vortexing. Samples were incubated for 2 $\mathrm{h}$ at $56^{\circ} \mathrm{C}$ under rotation $(500 \mathrm{rpm})$ to allow complete lysis, followed by $1 \mathrm{~h}$ at $90^{\circ} \mathrm{C}$. Additional $200 \mu \mathrm{l}$ of Buffer $\mathrm{AL}$ was added and sample was mixed by vortexing, followed by addition of $200 \mu$ pure ethanol and mixing by vortexing. Lysate was then transferred onto the QIAamp MinElute column in a $2 \mathrm{ml}$ collection tube, centrifuged at $6000 \mathrm{x}$ g for 1 min, followed by washes with Buffer AW1 and AW2. Membrane was then left to dry and DNA was eluted using 20-100 $\mu \mathrm{ldd} \mathrm{d}_{2} 0$. DNA integrity and quantification was measured using the TapeStation 2200 (Agilent) platform and the High Sensitivity D1000 Screen Tape, according to manufacturer's instructions.

\section{Genomic analysis with next generation sequencing}

NGS libraries were prepared from 50 to $400 \mathrm{ng}$ of DNA using the KAPA HyperPlus Kit (Kapa Biosystems, Wilmington, MA, USA) and IDT UDI 8 bp adapters (Integrated DNA Technologies, Coralville, USA), following the manufacturer's protocol, including dual-SPRI size selection of the libraries (250-450 bp). To optimise enrichment and reduce off-target capture, pooled, multiplexed, amplified pre-capture libraries (up to 20 samples per hybridization) were hybridized overnight using $1 \mu \mathrm{g}$ of total DNA to a custom design of DNA baits complementary to the genomic regions of interest (NimbleGen SeqCap EZ library, Roche, Madison, WI, USA). Hybridised DNA was PCR amplified and products purified using AMPure XP beads (Beckman Coulter, Danvers, MA, USA) and quantified using the Qubit dsDNA High Sensitivity Assay Kit with the Qubit 3.0 fluorometer (Invitrogen, Carlsbad, CA), and High Sensitivity D1000 TapeStation (Agilent, Santa Clara, USA).

Sequencing was performed on a NovaSeq6000 with $150 \mathrm{bp}$ paired-end reads and v1.5 chemistry, according to the manufacturer's instructions. NovaSeq (Illumina, San Diego, CA, USA) runs were analysed using an in-house pipeline. For the demultiplexing bcl2fastq (v2.19) was used to isolate reads for each sample. The reads were aligned to the reference genome build GRCh37/Hg19 using Burrows-Wheeler
Aligner (BWA-MEM), followed by the marking of PCR duplicates and calculation of various quality control (QC) metrics using Picard software (v2.21.1). Copy number was estimated by generalizing the coverage expected for a copy of any given gene, taking the average coverage across all target regions to estimate the average coverage of one target region. Any ratio below 0.5 -fold was defined as a potential deletion, whereas a ratio above 2.4 was flagged as a potential amplification if $80 \%$ of the target regions had exceeded the thresholds. Manta (v0.29.6) was used for the detection of structural variants. Genome Analysis Toolkit (GATK) was used for realigning around indels to improve indel calling and base quality score recalibration for adjusting systematic errors made by the sequencer when estimating quality scores of each base call. Finally, GATK was also used for variant calling using HaploType Caller for tumour only analysis (limit of detection $10 \%$ ) and MuTect2 for tumour paired analysis. VCF files from unpaired samples were annotated using Illumina Varinat Studio v3.0, and the variants checked manually on IGV using different allele frequency plots.

\section{Statistical analysis}

Quantitative results are expressed as mean \pm standard error of the mean. Statistical analysis was performed using the Mann-Whitney U-test and graphs were prepared using GraphPad. A $p<0.05$ was considered statistically significant.

\section{Results}

Patients' samples used in this study are listed in Table 3. We collected renal tumour samples, and matched non-affected kidney where possible, from 24 patients, which following histopathological analysis were identified as clear cell (ccRRCC) (58\%), papillary RCC (21\%), chromophobe RCC (4\%), oncocytoma (13\%) and urothelial cell carcinoma (4\%).

In this study, only samples from ccRCC were included. ccRCC samples were further classified (Table 4) based on their nuclear grading using the Fuhrman classification into grade $1(7 \%)$, grade $2(36 \%)$, grade $3(36 \%)$ and grade 4 (21\%). From the isolated cells, 10 out of 12 samples (83\%) successfully expanded in 2D in vitro cell culture, but only 5 out of 9 samples (56\%) could be passaged beyond 2 passages, with those samples being mainly of Grade 3 and Grade 4.

We tested 2 methods to culture cancer cells. Either as mixed, non-sorted cell cultures or as sorted cultures where the stromal subpopulations (fibroblasts and CD $31^{+}$cells, Supplementary Figure 1) were cultured separately. Cancer cells from 7 patients from either sorted or mixed non-sorted cell isolates were first cultured in low-attachment plates to 
Table 3 Patient and sample data

\begin{tabular}{llllll}
\hline Type & Clear cell & Papillary & Chromophobe & Oncocytoma & Transitional cell \\
\hline Number & $58 \%(14 / 24)$ & $21 \%(5 / 24)$ & $4 \%(1 / 24)$ & $13 \%(3 / 24)$ & $4 \%(1 / 24)$ \\
Gender (M:F) & $7: 7$ & $5: 0$ & $0: 1$ & $2: 1$ & $0: 1$ \\
Age average (range) & $57(43-76)$ & $58(49-68)$ & 66 & $74(69-79)$ & 75 \\
Range of sample weight (g) & $0.3-8.6$ & $0.3-8.0$ & 4.2 & $0.2-1.0$ & 1.3 \\
Range of total cells isolated & $0.16-17.4 \times 10^{6}$ & $0.11-10.8 \times 10^{6}$ & $7.6 \times 10^{6}$ & $2.63-8.97 \times 10^{6}$ & $10.75 \times 10^{6}$ \\
2D cell growth & $58 \%(7 / 12) 2 *$ & $100 \%(5 / 5)$ & $*$ & $100 \%(3 / 3)$ & $100 \%(1 / 1)$ \\
\hline
\end{tabular}

*Cells frozen following isolation

Table 4 Growth of Clear Cell Renal Cell Carcinoma according to nuclear grading

\begin{tabular}{lllll}
\hline Fuhrman Nuclear Grade & 1 & 2 & 3 & 4 \\
\hline Number & $7 \%(1 / 14)$ & $36 \%(5 / 14) *$ & $36 \%(5 / 14)^{*}$ & $21 \%(3 / 14)$ \\
2D cell growth (p0-p1) & $100 \%(1 / 1)$ & $75 \%(3 / 4)^{* *}$ & $75 \%(3 / 4)$ & $100 \%(3 / 3)$ \\
2D cell growth p2 $>$ & $0 \%(0 / 1)$ & $50 \%(1 / 2)$ & $33 \%(1 / 3)$ & $100 \%(3 / 3)$ \\
Spheroid formation & $100 \%(1 / 1)$ & $33 \%(1 / 3)$ & $100 \%(1 / 1)$ & $0 \%(0 / 2)$ \\
Direct 3D culture & N/A & 0 & 1 & 2 \\
Indirect 3D culture & Spheroid in 3D & Spheroid in 3D (1) & Spheroid in 3D (1) & Cells in 3D (3) \\
& & Cells in 3D (1) & Cells in 3D (1) & \\
\hline
\end{tabular}

*One sample cells frozen following isolation

**One sample had infection in the culture observe their ability to form spheroids (Figure 1). Spheroids formed in only 3 of the 7 samples and this was independent of cell sorting. However, we observed a significant increase in spheroid size in non-sorted cell population when compared to the sorted cell population (Figure 1a). Furthermore, when comparing different cell culture mediums for spheroid formation, we observed no significant difference between the two media used, either Spheroid medium or Stem Cell Medium, for each cell population. Culturing the formed spheroids in stiff collagen for up to 21 days maintained their integral structure, viability, and expression of both CK8 and vimentin (Figure 1b).

Culturing the sorted cell populations (fibroblasts, CD31 ${ }^{+}$ and remaining cancer cells) in specific media did not result in specific outgrowth of any of these cell subpopulations. All cells were positive for CK8 and vimentin, and showed similar morphology to the cells from mixed, non-sorted populations (Figure 1c, Supplementary Figure 1-2). For further experiments, morphology, and expression of CK8 and vimentin changed according to the original tumour grade (Figure 1d). Cells from Grade 4 tumour showed heterogenous expression of CK8, with some cells strongly positive and some cells not expressing CK8, while vimentin expression decreased in all cells compared to cells grown from lower grade samples.

To confirm that our methods allow the culture of cancer cells from mixed cell populations, where the morphology of cells indicated a ccRCC phenotype, and exclude exclusive overgrowth of non-malignant epithelial or stromal cells, we assessed the presence of cancer cell surface markers using FACS and cancer mutations using Next Generation Sequencing (NGS).

To distinguish specific cell populations, we looked for the presence of the ccRCC marker carbonic anhydrase IX (CA9) by FACS. We found a higher percentage of $\mathrm{CA} 9^{+}$cells with increasing tumour grade, no $\mathrm{CA} 9^{+}$cells were found in matched healthy tissue (Fig. 2a,c). We also found that the number of cytokeratin $(\mathrm{CK})^{+}$cells was reduced in tumour samples compared to matched healthy tissue (Fig. 2b).

We further cultured freshly isolated malignant and nonmalignant epithelial kidney cells in soft and stiff matrices under either normoxia or physiological hypoxia (2\%) for 14 days. We found that non-malignant epithelial renal cells grew in both soft and stiff matrices under both hypoxia and normoxia. However, in soft matrices cells formed more elongated thin networks, while in stiff matrices, they arranged in sheet like structures, and could even form spheroid-like structures (Fig. 3).

On the other hand, cancer renal cells showed similar morphology independent of the matrix stiffness or oxygen concentration (Fig. 4).

Finally, we used targeted NGS to identify the presence of RCC specific mutations, such as VHL, or other cancer specific alterations in samples from different tumour grades and matched healthy tissue which had been grown in the stiff 3D cultures. Cancer specific alterations were 
(A)
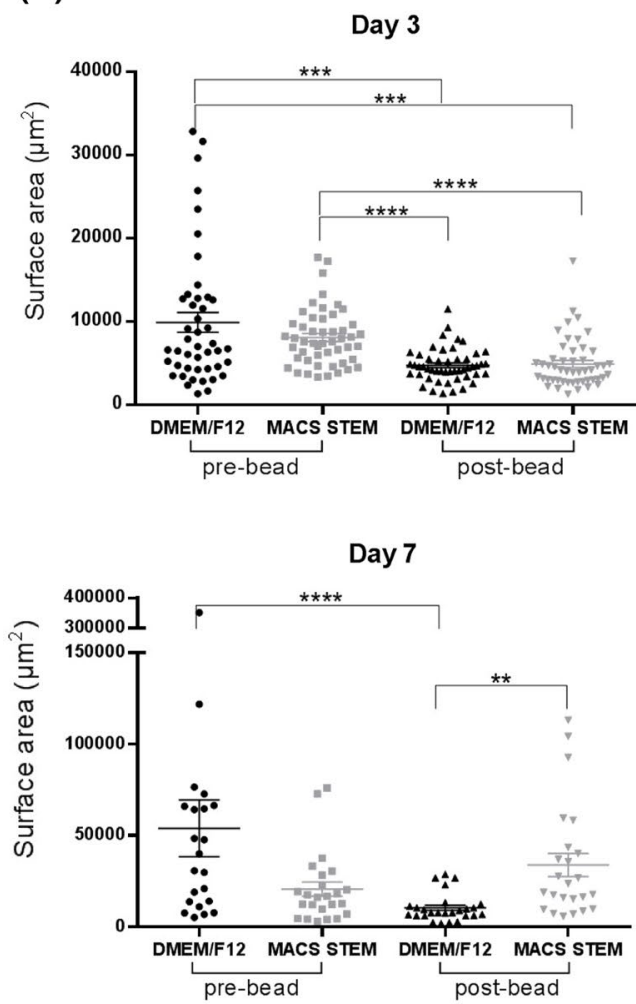

Day 10

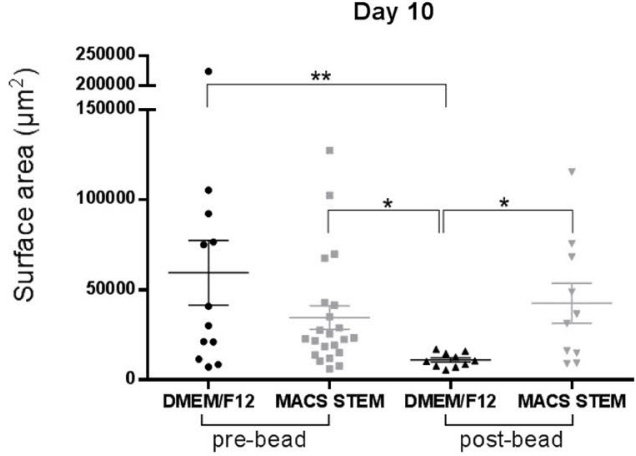

(B) Pre-bead
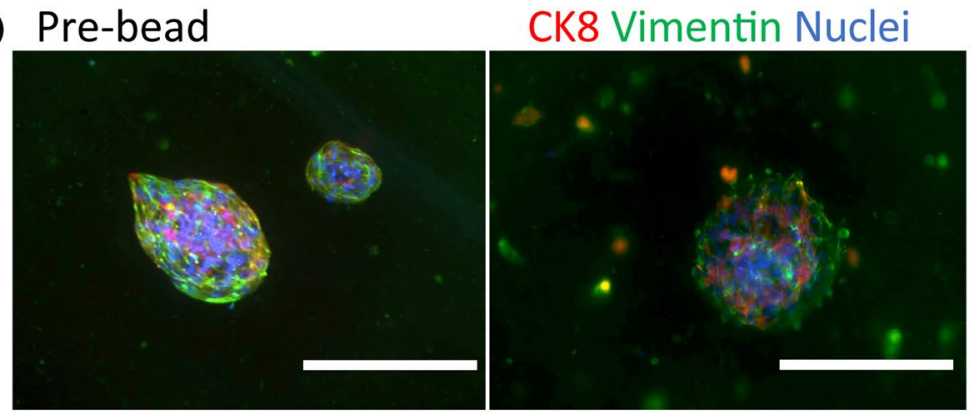

(C)
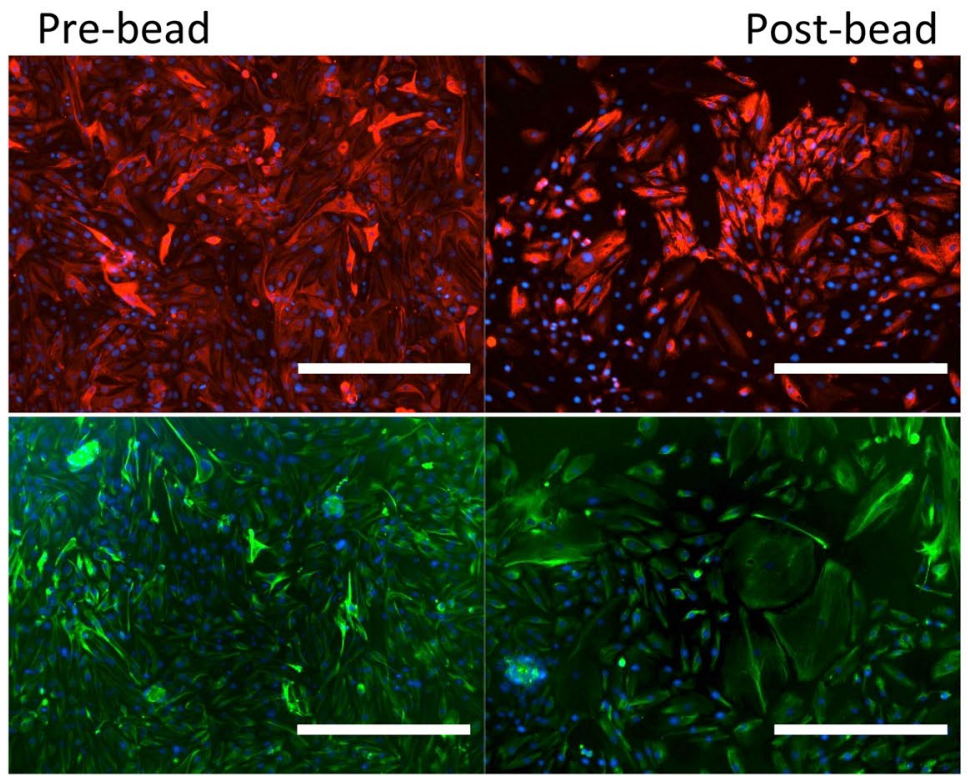

(D)

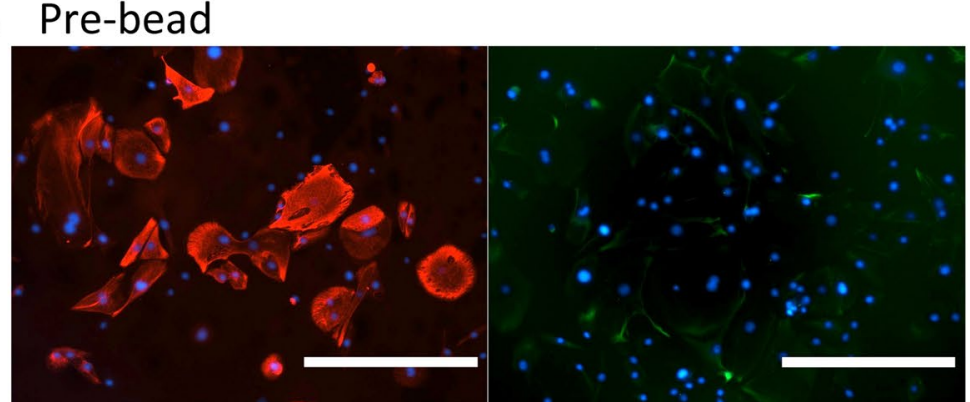

Fig. 1 Comparison of pre-sorted and post-sorted clear cell renal cell carcinoma isolated cell populations. a ccRCC showed poor formation of spheroids ( 3 out of 7 samples). Here is an example of successfully grown spheroids from pre- (pre-bead) and post-sorting for stromal cells (post-bead) cultured in a Spheroid Medium (DMEM/F-12) or a commercial Stem Cell Medium (MACS STEM). Their surface area $\left(\mu \mathrm{m}^{2}\right)$ was measured on day 3,7 and day $10 \mathbf{b}$ cultured spheroids were embedded in stiff collagen matrix and remained viable for

identified in all tumour samples compared to their corresponding normal tissue. This includes classical RCC alterations, such as $2 \mathrm{pb}$ duplication in the first exon of VHL(c.327_328dupCC) in case of R24 (Grade 4 ccRCC) (Fig. 5), previously associated with poor overall survival and resistance to therapy in RCC, and the likely driver up to 21 days, here fixed and stained for vimentin (Green) and CK8 (red) and nuclei (Blue) from pre-bead population cultured in Spheroid Medium (scale bar $400 \mu \mathrm{m}$ ). c cell samples grown in 2D from Grade 2 tumour showed positive CK8 and vimentin expression in both prebead and post-bead cell populations (scale bar $400 \mu \mathrm{m}$ ). d cells isolated from Grade 4 (pre-bead) had enlarged cell morphology, clear cell-like, with strong CK8 expression and weak vimentin expression (scale bar $400 \mu \mathrm{m}$ )

in this tumour. Alterations were also identified in the KMT2C and KMT2D (R13-Grade 3 ccRCC) and FGFR1 (R10-Grade 2 ccRCC). 
Fig. 2 Single cell analysis of expression profile for CA9 and cytokeratin in ccRCC samples. CA9 was highly expressed in ccRCC cells from Grade 3 and Grade 4 samples, while low expressions were observed in Grade 2 and non-malignant samples (a), pan-cytokeratin was highly expressed in cells from normal samples, while the expression varied in samples from Grade 3-4 samples (b), comparison of CA9 expression between normal and Grade 4 sample (c)
Fig. 3 Non-malignant kidney cells morphology in collagenbased scaffolds. Non-malignant kidney epithelial cells $(n=3)$ were grown in soft or stiff collagen-based scaffold for 14 days under normoxia or hypoxia. Scale bar $400 \mu \mathrm{m}$
(A)

CA9 expression

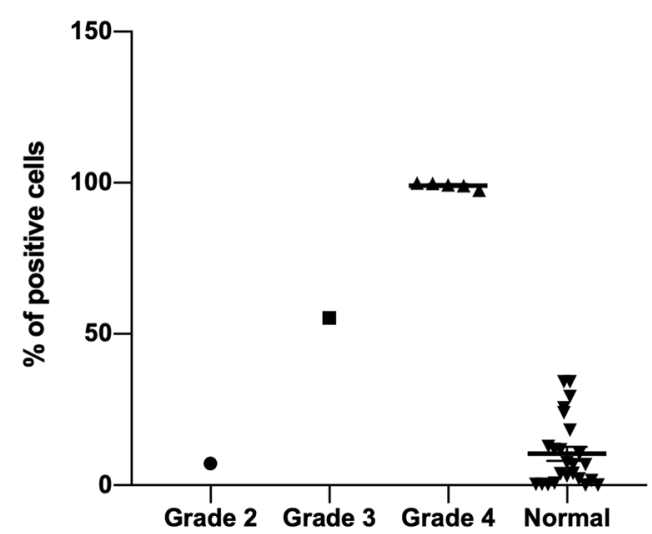

(C)
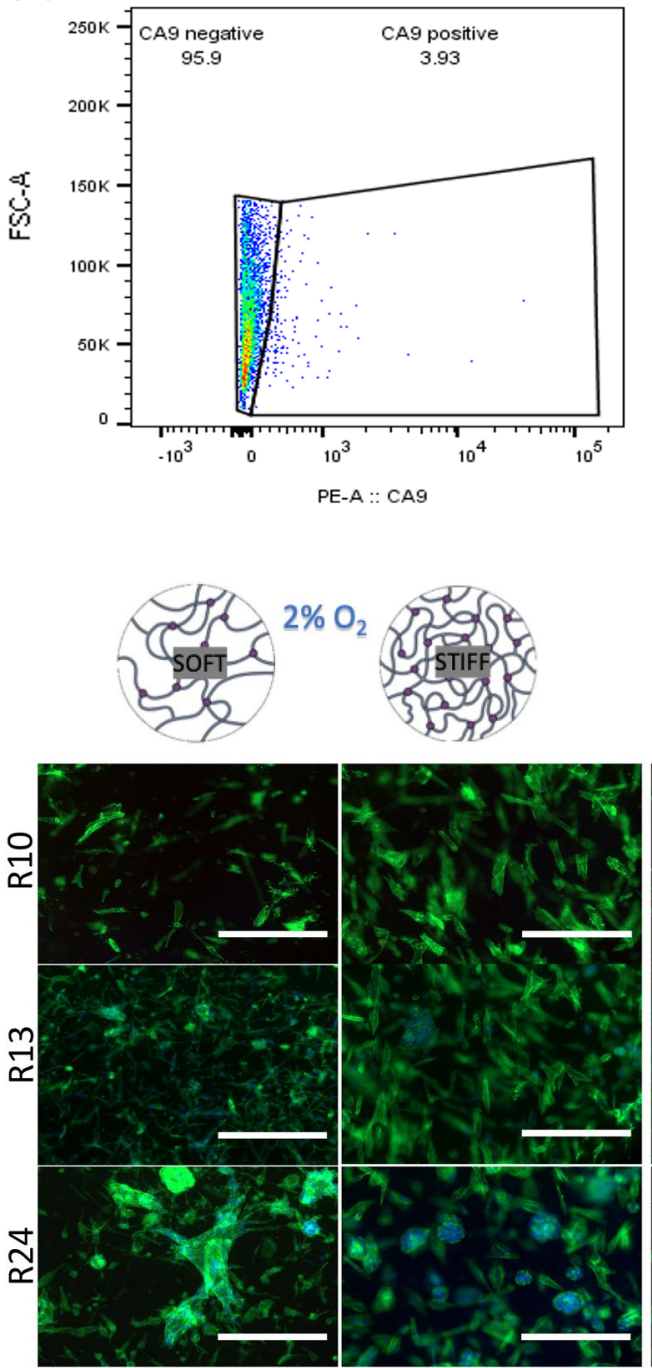

Pan-CK expression

(B)

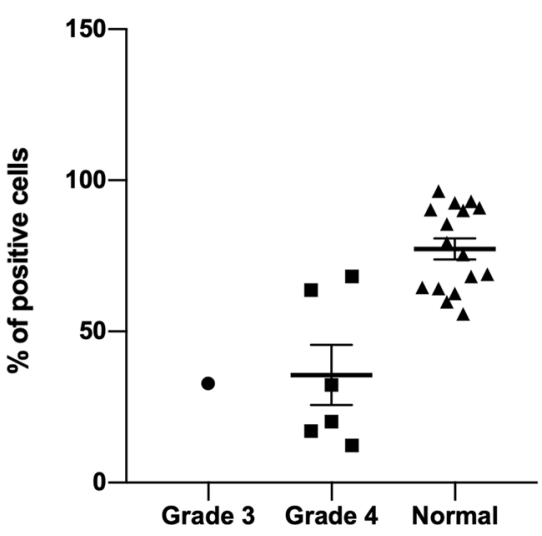

Grade 4
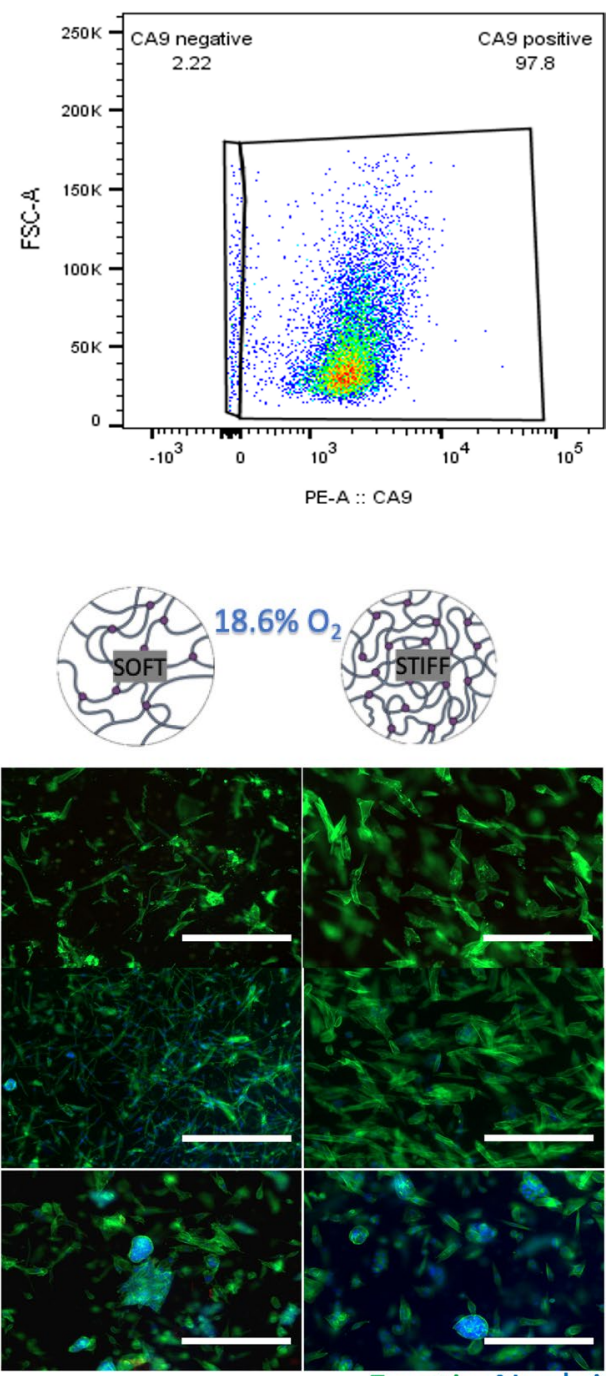

F-actin Nuclei 
Fig. 4 ccRCC cells morphology in collagen-based scaffolds. ccRCC cells $(n=3)$ were grown in soft or stiff collagen-based scaffold for 14 days under normoxia or hypoxia. Scale bar $400 \mu \mathrm{m}$
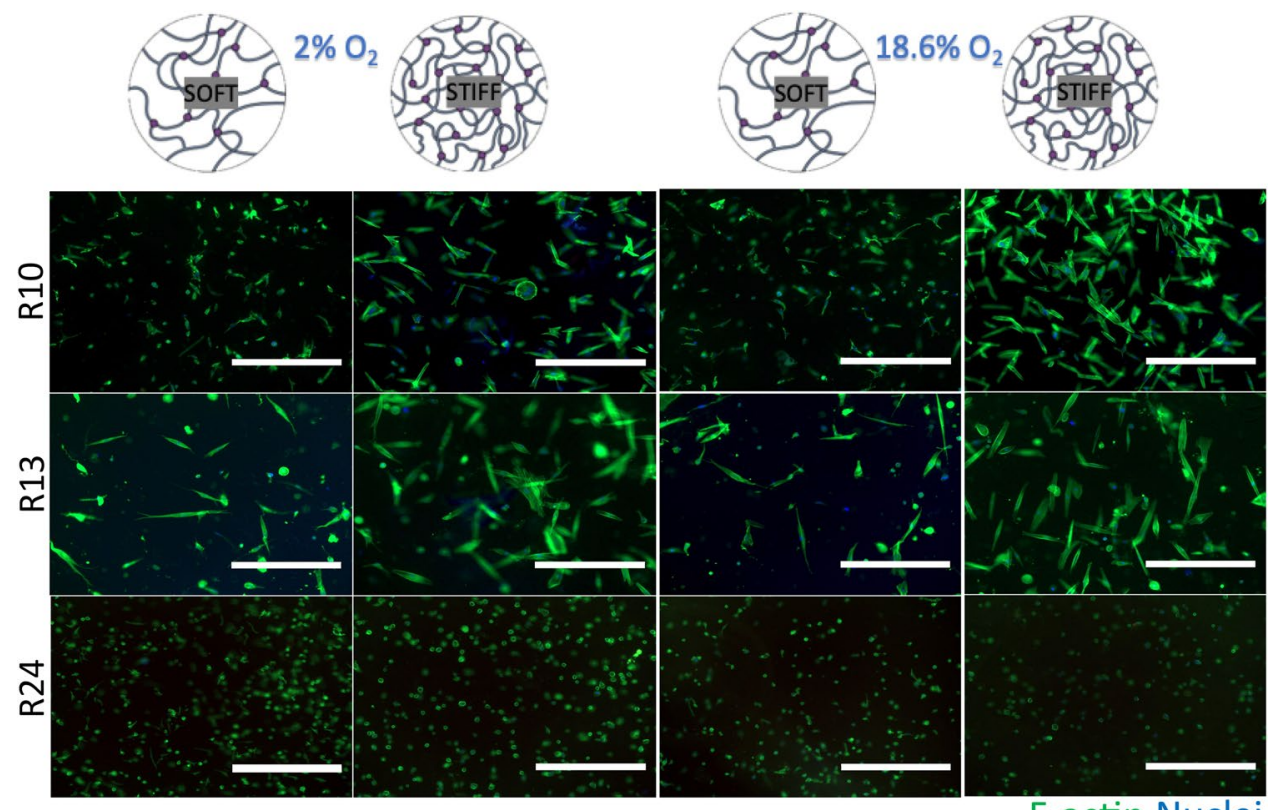

F-actin Nuclei
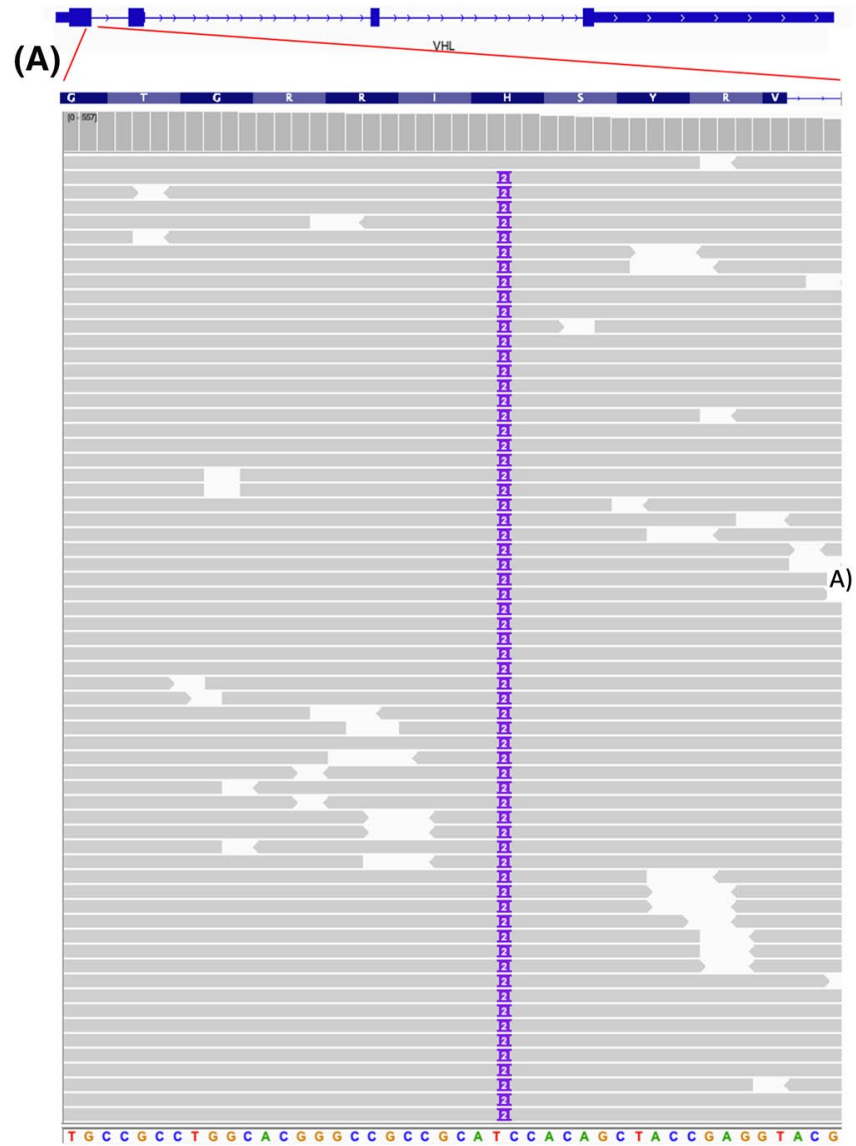

(B)

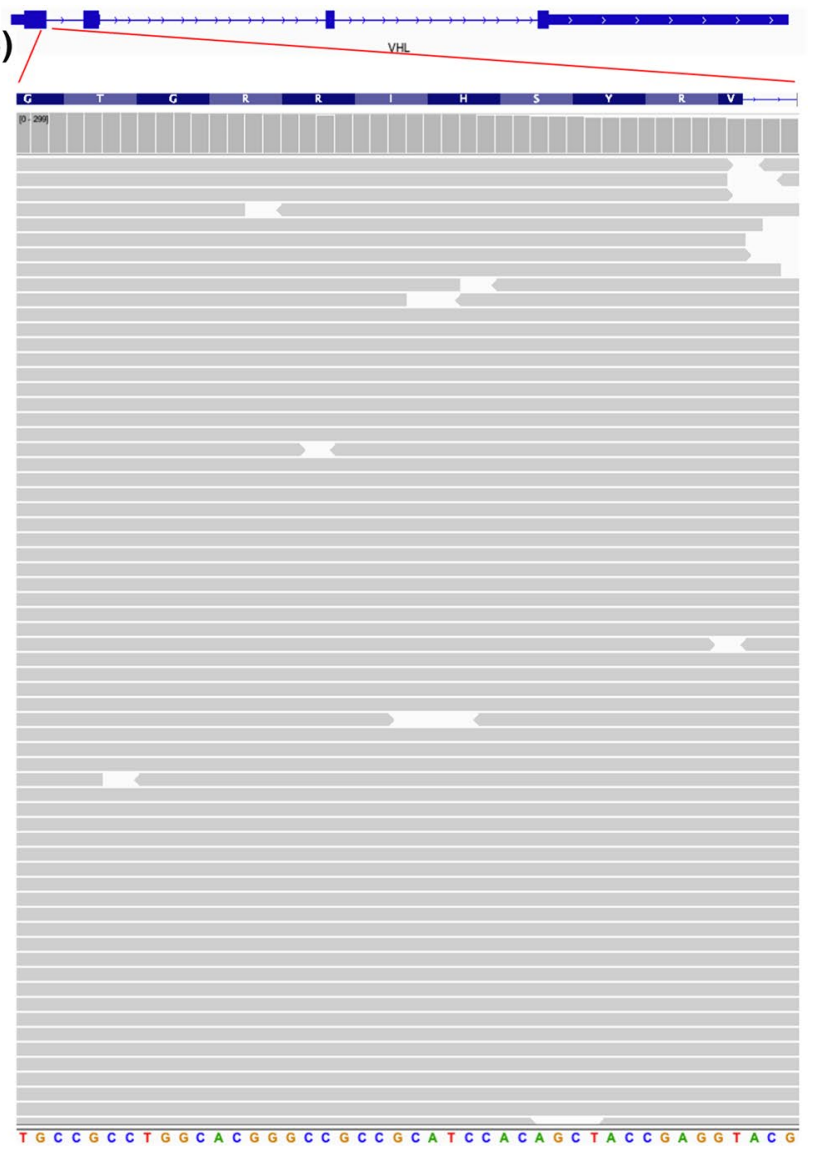

Fig. 5 Snapshots of the genetic analysis of VHL-1 gene in tumouroids grown from renal tissues from patients R24. a R24, tumour tissue: I109*InsCC, b R24, matched normal tissue. The 2-base pair inseration is indicated by 2 


\section{Discussion}

Kidney cancer encompasses a variety of histological subtypes. Our collection of post-nephrectomy tumour samples resulted in samples of clear cell RCC (58\%), papillary RCC (21\%), chromophobe RCC (4\%), oncocytoma (13\%) and urothelial cell carcinoma (4\%). The efficacy in establishing organoid cultures differs depending on the renal carcinoma subtype. For paediatric kidney tumours, the efficacy was $75 \%$ for Wilms tumours, $100 \%$ for malignant rhabdoid tumours, and $75 \%$ for renal cell carcinomas, while non-malignant kidney had $100 \%$ efficacy (Calandrini et al. 2020). For this study we focused on samples from clear cell renal cell carcinoma (ccRCC) of different grades as they were the most frequent and to allow comparability results. The efficacy of $2 \mathrm{D}$ expansion was $83 \%$, but long-term culture was only established in $56 \%$ of samples, mainly of Grade 3 and Grade 4. Cells isolated from the adjacent non-malignant part of the kidney had $100 \%$ efficacy in 2D growth. This highlights early cancer vulnerabilities upon dissociation from tissue and its microenvironment. Previously, limitations in primary cancer cell culture were reported to involve overgrowth by tumourassociated spindle cells or normal epithelial cells (Gao et al. 2014), however, in our study, culturing non-sorted or sorted populations enriched for cancer cells, resulted in similar growth of cancer cells in 2D and spheroids. ccRCC organoids in Matrigel were shown previously to lose their ability to form cohesive structure in long-term (several weeks) (Grassi et al. 2019), while we showed that the integrity of cancer spheroids can be maintained in stiff 3D collagen matrix for up to 21 days. Additionally, cells that were specifically selected during isolation using fibroblast or endothelial cell markers, did not expand as the selected subpopulations, but instead were positive for both CK8 and vimentin. ccRCC cells have been shown to display mesenchymal characteristics (Landolt et al. 2017; Sugimoto et al. 2016), whilst also showing highly vascularised phenotype (Qian et al. 2009; Yao et al. 2007) with a preference to endothelial like conditions in vitro and a display of vascular mimicry (Serova et al. 2016). Therefore, it is very likely that the specific cell sorting of stromal cells is not an appropriate approach to separate heterogenous ccRCC population as the cancer cells may express the same markers. While the higher grade ccRCC cancer cells showed distinctive morphology characteristic of their cancer type-enlarged cells with clear cytoplasms (Muglia and Prando 2015), the lower grade cells showed morphology similar to the epithelial cells isolated from normal samples. Previous work in this area has highlighted the potential for normal primary epithelial cells to overgrow primary cancer cells in vitro (Kodack et al. 2017). Our FACS analysis showed increase in CA9 positive cells-marker of ccRCC-with samples from higher tumour grade, confirming presence of ccRCC cells.

Isolated cells were also successfully cultured in soft and stiff 3D collagen-based matrices under either hypoxia or normoxia. Previously, ccRCC cultured directly in Matrigel following isolation, grew only as single cells, though their CA9 expression was still high (Na et al. 2020). In our conditions non-malignant epithelial kidney cells formed either elongated thin networks (soft matrix) or sheet-like structure and spheroid-like structures (stiff matrix), while cancer cells had no difference in growth between soft and stiff cultures with similar disperse morphology. NGS analysis of cancer and non-malignant cells in stiff matrices, confirmed presence of cancer cells, with mutations varying between the analysed samples. This supports the use of 3D collagen-based matrices for direct culture of freshly isolated non-malignant and cancer cells.

There is ongoing need for personalised medicine and for improved disease models to mimic disease and patient heterogeneity. One of the key challenges is to extract cancer cells and maintain them in culture without affecting their viability or phenotype. Extensive 2D cell expansion can lead to clonal selectivity, and acquisition of phenotypic changes, prior to any relevant experimental testing. The ability of growing freshly isolated cancer and normal cells directly in 3D allows for studying the cells already in correct microenvironment without causing any alterations due to a $2 \mathrm{D}$ cell culture. In this paper, we present an approach to isolate clear cell renal cell carcinoma cells from tumours of various grades. Along the process, we isolated non-malignant kidney epithelial cells from regions outside of the cancer margins. We showed that the cancer cells and kidney epithelial cells do not need selection or sorting, and through mechanical and chemical dissociation of tissue and culture of the isolated single cells in specific cell culture medium, we obtained cell cultures of interest. Furthermore, the cancer cells maintain their phenotype and genotype (CA9 expression, presence of specific ccRCC mutations) and can grow in 3D collagen-based matrices. While normal epithelial cells grow in both soft and stiff matrices, cancer cells show preference to stiffer gels-resembling the stiffer tumour microenvironment in vivo. This approach provides tools for further specialization of the 3D collagen scaffold to mimic closer the tumour microenvironment of choice-by addition of other relevant extracellular matrices or changing its stiffness.

Supplementary Information The online version contains supplementary material available at https://doi.org/10.1007/s12079-022-00666-2.

Acknowledgements Authors would like to thank all the patients and hospital staff that made the sample collection possible: surgeons, nurses, histopathologists. This work is independent research funded by the National Institute for Health Research (NIHR) under its Invention 
for Innovation (i4i) Programme (Grant reference Number II-LA-081320002). The views expressed in this publication are those of the authors and not necessarily those of the National Health Service (NHS), the NIHR or the Department of Health. Mark Emberton is a NIHR Senior Investigator and receives research support from the United Kingdom's NIHR UCLH/UCL Biomedical Research Centre. Joana B. Neves is funded by an MRC Clinical Research Training Fellowship. Maxine G.B. Tran receives research support from NIHR, Royal Free Charity, St Peter's Trust and Kidney Cancer UK.

Author contributions A.N. designed and performed the experiments, collected tissue samples, prepared figures and wrote the manuscript, K.S. and P.A.R. helped with performing the experiments, T.A., A.F., N.P. and R.H. performed the NGS analysis, J.B.N. helped consenting patients, collecting samples and clinical data, discussed experimental approaches/design, S.E.S. provided the tissue samples, M.G.B.T. managed the ethical approvals and access to patient samples, M.E. provided funding, M.L. and U.C. provided funding, designed the study, supervised the research work, wrote the manuscript. All authors have seen and commented on the final manuscript.

\section{Declarations}

Conflict of interest Authors declare no potential conflict of interest with respect to the research, authorship, and/or publication of this article.

Ethical approval Tissue samples were obtained with informed consent from patients undergoing nephrectomy at the Specialist Centre for Kidney Cancer, Royal Free Hospital NHS Foundation Trust (London, UK; REC reference Number: 16/WS/0039). The study was performed in accordance with the Declaration of Helsinki.

Open Access This article is licensed under a Creative Commons Attribution 4.0 International License, which permits use, sharing, adaptation, distribution and reproduction in any medium or format, as long as you give appropriate credit to the original author(s) and the source, provide a link to the Creative Commons licence, and indicate if changes were made. The images or other third party material in this article are included in the article's Creative Commons licence, unless indicated otherwise in a credit line to the material. If material is not included in the article's Creative Commons licence and your intended use is not permitted by statutory regulation or exceeds the permitted use, you will need to obtain permission directly from the copyright holder. To view a copy of this licence, visit http://creativecommons.org/licenses/by/4.0/.

\section{References}

Bensamoun SF, Robert L, Leclerc GE, Debernard L, Charleux F (2011) Stiffness imaging of the kidney and adjacent abdominal tissues measured simultaneously using magnetic resonance elastography. Clin Imaging 35:284-287. https://doi.org/10.1016/j.clini mag.2010.07.009

Boehnke K, Iversen PW, Schumacher D, Lallena MJ, Haro R, Amat J, Haybaeck J, Liebs S, Lange M, Schäfer R, Regenbrecht CRA, Reinhard C, Velasco JA (2016) Assay Establishment and Validation of a High-Throughput Screening Platform for Three-Dimensional Patient-Derived Colon Cancer Organoid Cultures. J Biomol Screen 21:931-941. https://doi.org/10.1177/1087057116650965

Brown RA, Wiseman M, Chuo C-B, Cheema U, Nazhat SN (2005) Ultrarapid engineering of biomimetic materials and tissues: fabrication of nano- and microstructures by plastic compression. Adv Funct Mater 15:1762-1770. https://doi.org/10.1002/adfm. 200500042

Calandrini C, Schutgens F, Oka R, Margaritis T, Candelli T, Mathijsen L, Ammerlaan C, van Ineveld RL, Derakhshan S, de Haan S, Dolman E, Lijnzaad P, Custers L, Begthel H, Kerstens HHD, Visser LL, Rookmaaker M, Verhaar M, Tytgat GAM, Kemmeren P, de Krijger RR, Al-Saadi R, Pritchard-Jones K, Kool M, Rios AC, van den Heuvel-Eibrink MM, Molenaar JJ, van Boxtel R, Holstege FCP, Clevers H, Drost J (2020) An organoid biobank for childhood kidney cancers that captures disease and tissue heterogeneity. Nat Commun 11:1310. https://doi.org/10.1038/ s41467-020-15155-6

Cifola I, Bianchi C, Mangano E, Bombelli S, Frascati F, Fasoli E, Ferrero S, Di Stefano V, Zipeto MA, Magni F, Signorini S, Battaglia C, Perego RA (2011) Renal cell carcinoma primary cultures maintain genomic and phenotypic profile of parental tumor tissues. BMC Cancer 11:244. https://doi.org/10.1186/ 1471-2407-11-244

Dragoni S, Turin I, Laforenza U, Potenza DM, Bottino C, Glasnov TN, Prestia M, Ferulli F, Saitta A, Mosca A, Guerra G, Rosti V, Luinetti O, Ganini C, Porta C, Pedrazzoli P, Tanzi F, Montagna D, Moccia F (2014) Store-operated Ca2+ entry does not control proliferation in primary cultures of human metastatic renal cellular carcinoma. BioMed Res Int 2014:1-19. https://doi.org/10. 1155/2014/739494

Ebert T, Bander NH, Finstad CL, Ramsawak RD, Old LJ (1990) Establishment and characterization of human renal cancer and normal kidney cell lines. Cancer Res 50:5531-5536

Fujii M, Shimokawa M, Date S, Takano A, Matano M, Nanki K, Ohta Y, Toshimitsu K, Nakazato Y, Kawasaki K, Uraoka T, Watanabe T, Kanai T, Sato T (2016) A colorectal tumor organoid library demonstrates progressive loss of niche factor requirements during tumorigenesis. Cell Stem Cell 18:827-838. https://doi.org/10. 1016/j.stem.2016.04.003

Gao D, Vela I, Sboner A, Iaquinta PJ, Karthaus WR, Gopalan A, Dowling C, Wanjala JN, Undvall EA, Arora VK, Wongvipat J, Kossai M, Ramazanoglu S, Barboza LP, Di W, Cao Z, Zhang QF, Sirota I, Ran L, MacDonald TY, Beltran H, Mosquera J-M, Touijer KA, Scardino PT, Laudone VP, Curtis KR, Rathkopf DE, Morris MJ, Danila DC, Slovin SF, Solomon SB, Eastham JA, Chi P, Carver B, Rubin MA, Scher HI, Clevers H, Sawyers CL, Chen Y (2014) Organoid cultures derived from patients with advanced prostate cancer. Cell 159:176-187. https://doi.org/10.1016/j.cell.2014.08. 016

Gedye C, Sirskyj D, Lobo NC, Meens J, Hyatt E, Robinette M, Fleshner N, Hamilton RJ, Kulkarni G, Zlotta A, Evans A, Finelli A, Jewett MAS, Ailles LE (2016) Cancer stem cells are underestimated by standard experimental methods in clear cell renal cell carcinoma. Sci Rep 6:25220. https://doi.org/10.1038/srep25220

Gerlinger M, Rowan AJ, Horswell S, Larkin J, Endesfelder D, Gronroos E, Martinez P, Matthews N, Stewart A, Tarpey P, Varela I, Phillimore B, Begum S, McDonald NQ, Butler A, Jones D, Raine K, Latimer C, Santos CR, Nohadani M, Eklund AC, Spencer-Dene B, Clark G, Pickering L, Stamp G, Gore M, Szallasi Z, Downward J, Futreal PA, Swanton C (2012) Intratumor heterogeneity and branched evolution revealed by multiregion sequencing. N Engl J Med 366:883-892. https://doi.org/10.1056/NEJMoa1113205

Grassi L, Alfonsi R, Francescangeli F, Signore M, De Angelis ML, Addario A, Costantini M, Flex E, Ciolfi A, Pizzi S, Bruselles A, Pallocca M, Simone G, Haoui M, Falchi M, Milella M, Sentinelli S, Di Matteo P, Stellacci E, Gallucci M, Muto G, Tartaglia M, De Maria R, Bonci D (2019) Organoids as a new model for improving regenerative medicine and cancer personalized therapy in renal diseases. Cell Death Dis 10:201. https://doi.org/10.1038/ s41419-019-1453-0 
Karthaus WR, Iaquinta PJ, Drost J, Gracanin A, van Boxtel R, Wongvipat J, Dowling CM, Gao D, Begthel H, Sachs N, Vries RGJ, Cuppen E, Chen Y, Sawyers CL, Clevers HC (2014) Identification of multipotent luminal progenitor cells in human prostate organoid cultures. Cell 159:163-175. https://doi.org/10.1016/j. cell.2014.08.017

Kodack DP, Farago AF, Dastur A, Held MA, Dardaei L, Friboulet L, von Flotow F, Damon LJ, Lee D, Parks M, Dicecca R, Greenberg M, Kattermann KE, Riley AK, Fintelmann FJ, Rizzo C, Piotrowska Z, Shaw AT, Gainor JF, Sequist LV, Niederst MJ, Engelman JA, Benes CH (2017) Primary patient-derived cancer cells and their potential for personalized cancer patient care. Cell Rep 21:3298-3309. https://doi.org/10.1016/j.celrep.2017.11.051

Köpf-Maier P, Kolon B (1992) An organoid culture assay (OCA) for determining the drug sensitivity of human tumors. Int J Cancer 51:99-107. https://doi.org/10.1002/ijc.2910510119

Köpf-Maier P, Zimmermann B (1991) Organoid reorganization of human tumors under in vitro conditions. Cell Tissue Res 264:563576. https://doi.org/10.1007/BF00319046

Kuroda N, Tanaka A (2014) Recent classification of renal epithelial tumors. Med Mol Morphol 47:68-75. https://doi.org/10.1007/ s00795-013-0033-0

Landolt L, Eikrem Ø, Strauss P, Scherer A, Lovett DH, Beisland C, Finne K, Osman T, Ibrahim MM, Gausdal G, Ahmed L, Lorens JB, Thiery JPaul, Tan TZea, Sekulic M, Marti H-P (2017) Clear cell renal cell carcinoma is linked to epithelial-to-mesenchymal transition and to fibrosis. Phys Rep 5(11):e13305. https://doi.org/ $10.14814 /$ phy 2.13305

Magdeldin T, López-Dávila V, Villemant C, Cameron G, Drake R, Cheema U, Loizidou M (2014) The efficacy of cetuximab in a tissue-engineered three-dimensional in vitro model of colorectal cancer. J Tissue Eng 5:204173141454418. https://doi.org/10.1177/ 2041731414544183

Magdeldin T, López-Dávila V, Pape J, Cameron GWW, Emberton M, Loizidou M, Cheema U (2017) Engineering a vascularised 3D in vitro model of cancer progression. Sci Rep 7:44045. https:// doi.org/10.1038/srep44045

Muglia VF, Prando A (2015) Renal cell carcinoma: histological classification and correlation with imaging findings. Radiol Bras 48:166-174. https://doi.org/10.1590/0100-3984.2013.1927

Na JC, Kim J-H, Kim SY, Gu Y-R, Jun D-Y, Lee HH, Yoon YE, Choi KH, Hong SJ, Han WK (2020) Establishment of patient-derived three-dimensional organoid culture in renal cell carcinoma. Investig Clin Urol 61:216. https://doi.org/10.4111/icu.2020.61.2.216

Nyga A, Loizidou M, Emberton M, Cheema U (2013) A novel tissue engineered three-dimensional in vitro colorectal cancer model. Acta Biomater 9:7917-7926. https://doi.org/10.1016/j.actbio. 2013.04.028

Qian C, Huang D, Wondergem B, Teh BT (2009) Complexity of tumor vasculature in clear cell renal cell carcinoma. Cancer 115:22822289. https://doi.org/10.1002/cncr.24238
Rutzky LP, Tomita JT, Calenoff MA, Kahan BD (1979) Human colon adenocarcinoma cells. III. In vitro organoid expression and carcinoembryonic antigen kinetics in hollow fiber culture. JNCI J Natl Cancer Inst. https://doi.org/10.1093/jnci/63.4.893

Sato T, Vries RG, Snippert HJ, van de Wetering M, Barker N, Stange DE, van Es JH, Abo A, Kujala P, Peters PJ, Clevers H (2009) Single Lgr5 stem cells build crypt-villus structures in vitro without a mesenchymal niche. Nature 459:262-265. https://doi.org/ 10.1038/nature07935

Sato T, Stange DE, Ferrante M, Vries RGJ, van Es JH, van den Brink S, van Houdt WJ, Pronk A, van Gorp J, Siersema PD, Clevers H (2011) Long-term expansion of epithelial organoids from human colon, adenoma, adenocarcinoma, and barrett's epithelium. Gastroenterology 141:1762-1772. https://doi.org/10.1053/j.gastro. 2011.07.050

Serova M, Tijeras-Raballand A, Dos Santos C, Martinet M, Neuzillet C, Lopez A, Mitchell DC, Bryan BA, Gapihan G, Janin A, Bousquet G, Riveiro ME, Bieche I, Faivre S, Raymond E, de Gramont A (2016) Everolimus affects vasculogenic mimicry in renal carcinoma resistant to sunitinib. Oncotarget 7(25):38467-38486. https://doi.org/10.18632/oncotarget.9542

Sugimoto M, Kohashi K, Itsumi M, Shiota M, Abe T, Yamada Y, Kuroiwa K, Naito S, Oda Y (2016) Epithelial to mesenchymal transition in clear cell renal cell carcinoma with rhabdoid features. Pathobiology 83:277-286. https://doi.org/10.1159/000445752

Valente MJ, Henrique R, Costa VL, Jerónimo C, Carvalho F, Bastos ML, de Pinho PG, Carvalho M (2011) A rapid and simple procedure for the establishment of human normal and cancer renal primary cell cultures from surgical specimens. PLoS ONE 6:e19337. https://doi.org/10.1371/journal.pone.0019337

van de Wetering M, Francies HE, Francis JM, Bounova G, Iorio F, Pronk A, van Houdt W, van Gorp J, Taylor-Weiner A, Kester L, McLaren-Douglas A, Blokker J, Jaksani S, Bartfeld S, Volckman $\mathrm{R}$, van Sluis P, Li VSW, Seepo S, Sekhar Pedamallu C, Cibulskis K, Carter SL, McKenna A, Lawrence MS, Lichtenstein L, Stewart C, Koster J, Versteeg R, van Oudenaarden A, Saez-Rodriguez J, Vries RGJ, Getz G, Wessels L, Stratton MR, McDermott U, Meyerson M, Garnett MJ, Clevers H (2015) Prospective derivation of a living organoid biobank of colorectal cancer patients. Cell 161:933-945. https://doi.org/10.1016/j.cell.2015.03.053

Yao X, Qian C-N, Zhang Z-F, Tan M-H, Kort EJ, Yang XJ, Resau JH, Teh BT (2007) Two distinct types of blood vessels in clear cell renal cell carcinoma have contrasting prognostic implications. Clin Cancer Res 13:161-169. https://doi.org/10.1158/1078-0432. CCR-06-0774

Publisher's Note Springer Nature remains neutral with regard to jurisdictional claims in published maps and institutional affiliations. 